\title{
City Branding of Denpasar City as a Creative City Through the Denpasar Festival Event
}

\author{
Yanti Setianti, Susanne Dida and Ni Putu Cynthia Uttari Putri
}

City Branding Denpasar City as a Creative

Program Study of Public Relations, Faculty of Communivcations, Universitas Padjadjaran, Jatinangor, Sumedang, West Java, Indonesia

\begin{abstract}
Purpose - The purpose of this research is to describe the Denpasar Festival event as a city branding program of Denpasar city. Through the Denpasar Festival event, we also want to give an idea of the city of Denpasar as a creative city.

Design/Methodology/Approach - This study uses a qualitative method. The data were obtained based on observations and interviews of the people involved in the Denpasar Festival Event. In addition, researchers also conducted data collection through the official website of the Denpasar city government.

Findings - In carrying out city branding of Denpasar city, the government routinely carries out the annual activities of Denpasar Festival. Denpasar Festival is a show of creative culture creativity of the people of Denpasar city, which is more inclusive in which people can enjoy and actively participate in displaying the results of their superior creations.

Originality/Value - Denpasar Festival Event can affect the city branding Denpasar city so that it can be used as an effective way in increasing public knowledge of city branding Bandung. Therefore, the event should be Denpasar Festival or other events to be maintained and even improved quality and quantity in every other event in the city of Denpasar
\end{abstract}

Keywords City branding, brand, brand strategy, Denpasar festival event

All papers within this proceedings volume have been peer reviewed by the scientific committee of the Malikussaleh International Conference on Multidisciplinary Studies (MICoMS 2017).

\section{Introduction}

Bali is a tourist destination of the world and has great tourism potential due to it's natural beauty, the diversity of art and culture, as well as the religious social life of its unique community with the majority of its Hindu population. The rapid development of tourism in Bali makes tourism an integral part of people's lives in Bali. The city of Denpasar is the capital of Bali province, in addition to having a number of potential tourist attractions as well as a barometer or representation of the image of Bali tourism (first image of Bali). As a tourist destination, the city of Denpasar has a number of tourist attractions that are not less interesting than other areas. Likewise, various supporting facilities such as tourism

(C) Yanti Setianti, Susanne Dida, Ni Putu Cynthia Uttari P. Published in the Emerald Reach Proceedings Series. Published by Emerald Publishing Limited. This article is published under the Creative Commons Attribution (CC BY 4.0) licence. Anyone may reproduce, distribute, translate and create derivative works of this article (for both commercial and non-commercial purposes), subject to full attribution to the original publication and authors. The full terms of this licence may be seen at http://creativecommons.org/licences/by/4.0/legalcode

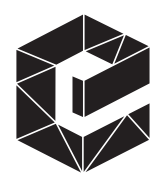

Emerald Reach Proceedings Series Vol. 1 Emerald Publishing Limited 2516-2853 DOI $10.1108 / 978-1-78756-793-1-00025$ 
Proceedings of MICoMS 2017

accommodation, restaurants, travel agencies, shopping centers, and health facilities are always ready to serve the needs of tourists. The policy measures that have been pursued by the Denpasar City Government in the framework of tourism development in Denpasar are stated in the Tourism Destination Development Program, which is called Activity Year of Denpasar Visit (Sightseeing Denpasar, 2008). Denpasar Sightseeing Program is a tourism program that embraces various arts and cultural activities, which are carried out continuously in Denpasar city every year since 2008. Denpasar Festival is a pre-eminent activity in Denpasar Sightseeing Program which is held periodically every end of year starting in 2008 when it is known as the Gajah Mada Festival. Along with that, Denpasar City Government intensively disseminate city branding Denpasar city entitled "Denpasar, The Heart of Bali," which adorn every advertisement of tourism. This is a good breakthrough done by the City Government of Denpasar in an effort to realize the creative city of Denpasar. Although explicitly visible, the vision tends to the cultural base of the course, but there is no harm in the spatial side should also be an important consideration for the Government of Denpasar as a policy giver. The courage to include creative city keywords in the formal development vision would need to be appreciated. By looking at the potential of Denpasar with historical background and characteristic of creative society, it is very possible that the city of Denpasar is able to meet the criteria of creative city development initiated by experts. Landry (2008) explains that as a whole there are seven prerequisites for realizing the creative city from various aspects, namely personal qualities, leadership, Diversity of species and human talents, organizational culture, Local identity, Urban space and facilities, and network dynamics. In addition, Evans et al. (2006) also provide some important aspects of the creative city gained from the experience of Toronto and New York. In addition to the above policy steps, efforts to support the development of tourism Denpasar is also done through the policy of realizing the City of Denpasar as a creative city (creative city) based on superior culture. The policy is implemented in the form of a number of activities that show the innovative spirit and creativity of the people of Denpasar. These activities include Denpasar Pet's Festival, Denpasar Hortikultura Festival, PekanSeniRemaja, Ritual RahinaTumpek, Sanur Village Festival, DTIK (Denpasar Information, Communication and Technology) Festival, The Exotic of Wastra dan Cinta by Anak Bangsa, Lomba Chef Senior, Denpasar Festival, Rare Festival, Utsawa Dharma Gita, Dialog Budaya Rembug Sastra, Photo Contest Denpasar Creative, Maha Bandana Prasadha Event, and Denpasar City Anniversary Ceremony that are always filled with diversity food heritage, music, fashion show, art market, farm market, seminars, and awards. Creativity is the Main Vision of Denpasar City Development. As a region with minimal natural resources, Denpasar has only three human resources, which is believed to be a key strategy of development in Denpasar city and is supported by the intensity of social and economic interaction. Creativity is the main capital to have competitiveness in facing global challenges. Creativity can have an economic impact, but of course there must be a motivation. One of the Government's steps to stimulate economic growth is by providing creative spaces such as the Denpasar Festival .Creative economic forms always come up with a distinctive added value, create their own "market," and succeed in absorbing labor and economic income. Pangestu as Minister of Tourism and Creative Economy period 20112014 in the Creative Economy Development Convention 2009-2015 when he served several reasons why the creative industries need to be developed in Indonesia mentioned, among others (1) make a significant economic contribution, (2) creating a positive business climate, (3) to build the image of national identity, (4) based on renewable resources, (5) create innovation and creativity which is a nation's competitive advantage, and (6) provides a positive social impact. One of the reasons for the development of creative industries is the 
positive impact that will affect the social life, business climate, economic improvement, and also affect the image of a region. Related to the effort to realize Denpasar as a creative city, Bappeda Denpasar since 2008 has tried to develop creative city concept by synergizing the six components mentioned.

\section{Methodology}

This research uses a qualitative method. According to Moleong (2007), it is qualitative research and is a research procedure to produce descriptive data in the form of written words or orally from the people and behavior that can be observed. According to Nazir (1988), descriptive method is a method in examining the status of a group of people, an object, a set of conditions, a system of thought, or a class of events in the present. The purpose of this descriptive research is to make description, picture, or painting systematically, factually, and accurately about facts, traits, and relationship between the phenomena studied. Meanwhile, according to Sugiyono (2005) states that the descriptive method is a method used to describe or analyze a research result but not used to make wider conclusions. Data utilized in this study were primary and secondary data. Primary data were results by interviewing event organizer Denpasar festival to know the development of Denpasar festival every year. And for secondary data were obtained through the official website of the city government Denpasar and various sources containing news about Denpasar Festival.

\section{Results and discussion}

\subsection{City branding definition}

Brand is an impression felt by consumers about a product or service. Brand is all tangible and intangible values that become uniqueness in a product or service. Brand is not just a symbol that distinguishes the product from one another, but the brand is all the attributes that come into the mind of the consumer when thinking about a particular product (Moilanen and Rainisto, 2009, p. 6). Brand is created and formed in one's mind. A brand can be created when a group of people in a particular group have the same thoughts about the personality of a brand. Brand is not created by the designer or managerial ranks of a company, but formed in the minds of consumers (Moilanen and Rainisto, 2009, p. 7). So when someone creates a new name or logo for a new product, he has created a brand. However, the brand is not a product but gives meaning to the product and defines the identity of the product in time and space. A brand is a promise, a perception, everything that a consumer sees, hears, reads, knows, feels about a product, a service, or a business. The brand also has a privileged position in the minds of consumers, based on past experience, association, and future expectations.

City branding can be said as a strategy of a country or region to create a strong positioning in the minds of their target market, such as positioning a product or service, so that countries and regions can be widely known throughout the world. City branding can be interpreted as a process of forming a city brand or an area to be known by the target market (investors, tourist, talent, and event) the city by using icons, slogans, exhibitions, as well as good positioning, in various forms of promotional media. The thing that makes a city or area to do city branding is to introduce the city or region with in depth and improve the image of the city itself. In addition, it can attract tourists both foreign and domestic tourists. In the making of city branding can attract investors to invest in the city and certainly can increase the value of trade (Gobe, 2012, p. 12). In every successful city branding, the city government should conduct a strategic check on trends within the community and the economy.
City Branding Denpasar City as a Creative City 
Proceedings of MICoMS 2017
Determine where the city's opportunities, skills, resources, and abilities are Find out about core values, attitudes, characteristics, and characteristics of the city in achieving the desired goals; And looking for the right combination that creates an interesting differentiation for various circles (Dinnie, 2011, p. 15).

This city branding activity requires each region to compete to create a certain image in the mind of broad community in representing the character of the city. The image of the city has the power in forming a city brand, even affecting the city itself.

\subsection{Results}

The city of Denpasar is the capital of Bali province which is very synonymous with the wealth of creativity in the arts and culture. The city of Denpasar is the capital of Bali province which is experiencing growth and development in all areas that continue to increase, giving a big influence on the city itself. Population growth averaged $4.05 \%$ per year with growth in various sectors, thus giving a major influence on the city of Denpasar, eventually leading to various problems that must be resolved by the administrative municipality. The city of Denpasar experienced rapid development physically and nonphysically.

Community attachment to Puri can be seen in Denpasar city as a cultural city, where people are bound by four big castle that play an important role, namely Puri Denpasar, Puri Pemecutan, Puri Satria, and Puri Kesiman. There are two castles that play an important role, namely Puri Kesiman and Puri Denpasar. Through this power, then the city of Denpasar developed in aspects of economic, political, social, and cultural education.

As other creative cities in Indonesia, one of the efforts undertaken by the Government of Denpasar in order to realize creative economy-based tourism in the city of Denpasar is the sixth implementation of the Denpasar Festival which is held periodically every year. For the bureaucrats, scholars, culturalists of Denpasar, this festival is expected to be a vehicle for the preservation of local culture from the influence of globalization, excavation, and the development of art and culture forms in the form of innovative creativity so that the values of local wisdom are maintained as well as a vehicle for the development of creative economy become the target of economic development of the people of Denpasar. Denpasar City Government always strives to advance its society by increasing the spirit of entrepreneurship and creativity, without leaving local genius owned by the people of Denpasar. The arrival of foreign tourists to Bali in January reached 350,592 people, with foreign tourists coming through the airport as many as 343,663 people and through the port of 6,929 people. The number of foreign tourists to Bali in 2016 rose by $16.19 \%$ compared with 2015. In carrying out city branding, Denpasar City Government routinely carries out the annual activities of Denpasar Festival. Denpasar Festival is a show of creative cultural creativity of the people of Denpasar city, which is designed as a show of creativity of the people of Denpasar city which is more inclusive in which people can enjoy and actively participate in displaying the results of their superior creations. Denpasar Activity festival is held with the co-operation of Denpasar City Government Institution with Local Device Work Unit and Deva Communication as an event organizer. Denpasar Festival is the momentum of the year-end celebration that is always crowded, full of excitement, and passionate public spirit to enjoy everything that is presented. Minister of Tourism, Arief Yahya, gave appreciation of the Denpasar Festival 2016 as an effort to increase domestic and foreign tourists visit to Bali. The event is aimed at preserving and developing Bali tourism, targeting its visitors as much as 60,000 people with a tourism economy value of 6.5 billion. According to IB Dharmawijaya Mantra in Pesona Indonesia Travel website, Denpasar Festival 2016 event has a theme which means eight steps of development of Denpasar city 
more qualified to City Smart, Competent City, law enforcement supremacy in governance, to Heritage City, improvement of welfare, participation development Society as an agent of change, the development of creative economy that highlighted as new strategy of development of Denpasar city. Through the Denpasar Festival event, Denpasar City Government also wants to convey to the visitors both local people and tourists that the city of Denpasar has a cultural diversity that is still very thick and as a city that became the center of Denpasar city, administration wants to care for a culture of tradition with innovation so that there is creativity of the city that can be enjoyed.

City Branding Denpasar City as a Creative City 371

\section{Conclusion}

Denpasar city as the capital of Bali province as the Island of the Gods is doing vigorous city Branding Denpasar which is done with some activities called the Denpasar Festival. The event is conducted by a means to increase community's awareness about the culture and knowledge of the community about the city of Denpasar further. To strengthen the city of branding, Denpasar city government improves facilities and activities for local and foreign community more familiar with the city of Denpasar. Besides, Denpasar city has been popular with the slogan "The Heart of Bali", so many people have a perception that the Denpasar city is very open to local and national cultural differences, and also the Denpasar Festival event makes people want to come back to the Denpasar city as the capital of Bali province.

\section{References}

Dinnie, K. (2011). City Branding: Theory and Cases. Palgrave Macmillan, London.

Evans, G. Jo Foord. Meric S Gertler. Lori Tesolin. Sarah Weinstock. (2006). Strategies for Creative Spaces and Cities: Lessons Learned. Research Team: Cities Institute, London Metropolitan University

Gobe, M. (2012). Citizen Brand. Jakarta: Erlangga.

Landry, C. (2008). The Creative City: A Toolkit for Urban Innovators 2nd edition. Comedia.

Moilanen, T. and Rainisto, S. (2009). How to Brand Nations, Cities and Destinations, A Planning Book for Place Branding. Palgrave Macmillan, USA.

Moleong, L.J. (2007). Metodologi PenelitiancKualitatif. PT. RemajaRosdakarya, Bandung.

Nazir, Moh. (1988). MetodePenelitian, Jakarta: Ghalia Indonesia.

Sugiyono. (2005). MetodePenelitianKuantitatif Kualitatif Dan R\&D. Bandung: Alfabeta

\section{Website}

https://denpasarkota.go.id/index.php/index.php/prestasi/?pages=2 accessed on 19 May 2017, at 13.07 wib.

http://pesona.indonesia.travel/berita/denpasar-festival-2016/ accessed on 20 May 2017, at 21.22 wib.

\section{Corresponding author}

Yanti Setianti can be contacted at yanti.setianti@unpad.ac.id/yantisetianti@gmail.com 